\title{
LOBBYING AND THE LAW
}





\section{EDGAR LANE}

\section{LOBBYING}

AND THE LAW

BERKELEY AND LOS ANGELES

1964 UNIVERSITY OF CALIFORNIA PRESS 
Untrensity of CaLIfonnu pass

eERxeley and los anceles, calipornia

CAMERIDGE UNIVEESITY PAES

LONDON, INGLAND

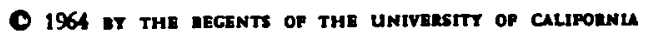

LIERART OF CONGRESS CATALOC CARD nUmERE: 64-16059

PAJNTED IN THE UNItED states OP aMrMca 
For Rutb 
